\title{
INHIBITION OF POST-GANGLIONIC MOTOR TRANSMISSION IN VAS DEFERENS BY INDIRECTLY ACTING SYMPATHOMIMETIC DRUGS
}

\author{
N. AMBACHE, LINDA P. DUNK, J. VERNEY \\ and M. ABOO ZAR
}

From the Medical Research Council, Department of Physiology, Royal College of Surgeons of England, Lincoln's Inn Fields, London WC2A 3PN

INIBIÇÃO DA TRANSMISSÃO MOTORA PŌS-GANGLIONAR NOS VASOS DEFERENTES POR AÇÃO INDIRETA DE DROGAS SIMPATOMIMÉTICAS

RESUMO:

1 - Usando um campo elétrico estimulador, com séries curtas de pulsos (menor que 10 por série), a transmissão motora pós-ganglionar nos vasos deferentes de mamíferos foi posteriormente analisada do ponto de vista farmacológico.

2 - Em preparações feitas de cobaia, ratos e coelhos os efeitos de drogas indiretamente simpatomiméticas, tiramina e cocaína puderam ser explicados totalmente na base da ação de liberação de noradrenalina endógena.

3 - Tiramina produziu uma contração em vasa retirada de ratos normais, mas não agiu em cobaias normais. A contração causada pela tiramina foi devida à liberação de noradrenalina endógena porque não é observada em ratos reserpinizados e porque foi abolida na vasa normal pela fenoxibenzamina ou fentolamina, assim negando a suposta inacessibilidade aos $\alpha$-bloqueadores dos $\alpha$-adrenoreceptores motores ativados pela noradrenalina endógena.

4 - Fenoxibenzamina ou fentolamina, foi incapaz de bloquear a transmissão motora pós-ganglionar em vasa de ratos e cobaias.

5 - Tiramina inibe intensamente a transmissão motora em vasa de cobaias normais, não agindo nos reserpinados.

6 - Tiramina produz inibição da transmissão motora nas preparações tratadas com fenoxibenzamina obtidas de ratos normais, porém não inibe as de ratos reserpinizados.

Número especial em homenagem ao Prof. Dr. Paulo Sawaya, no ano jubilar de seu magistério. 
7 - Cocaína inibe a transmissão motora nos vasa de cobaia e ratos. Este efeito não foi devido à anestesia local ou à ação depressora sobre a musculatura lisa porque isto não ocorre nas preparações feitas com animais reserpinizados.

8 - O efeito inibidor da tiramina ou cocaína não foi abolido pelo bloqueio dos $\beta$-adrenoreceptores com propranolol.

9 - Embora a reserpinação neutralize a inibição da tiramina e cocaína, não afeta a ação inibidora da noradrenalina ou do $\mathrm{PGE}_{2}$.

10 - A indometacina e meclofenamato de sódio, as quais bloqueiam a síntese de prostaglandina, não afetam a ação inibidora contrátil da noradrenalina, tiramina ou cocaína.

11 - Estes resultados fornecem bases suplementares para se concluir que a transmissão motora pós-ganglionar para os vasos deferentes é não adrenérgica nestas espécies e assegura à noradrenalina liberada endogenamente uma função inibidora sobre a transmissão motora.

\section{SUMMARY}

1. Using field stimulation with short trains of pulses $(<10$ per train), the post-ganglionic motor transmission in the mammalian was deferens has been further analysed pharmacologically.

2. In preparations taken from guinea-pigs, rats and rabbits the effects of the indirectly sympathomimetic drugs, tyramine and cocaine, could be explained entirely on the basis of the actions of released, endogenous noradrenaline.

3. Tyramine produced a contraction in vasa taken from normal rats but not from normal guinea-pigs. The tyramine contraction was due to release of endogenous noradrenaline because it was not seen in preparations taken from reserpinized rats and because it was abolished in normal vasa by phenoxybenzamine or phentolamine, thus denying the supposed inaccessibility, to $\alpha$-blockers, of the motor $\alpha$-adrenoceptors activated by endogenous noradrenaline.

4. Phenoxybenzamine or phentolamine failed to block post-ganglionic motor transmission in rat and in guinea-pig vasa.

5. Tyramine strongly inhibited motor transmission in vasa taken from normal but not from reserpinized guinea-pigs.

6. Tyramine produced inhibition of motor transmission in phenoxybenzamine-treated preparations taken from normal but not from reserpinized rats.

7 Cocaine inhibited motor transmission in guinea-pig and in rat vasa. This effect was not due to a local anaesthetic or to a smoothmuscle depressant action because it did not occur in preparations taken from reserpinized animals.

8. The inhibitory effect of tyramine or cocaine was not abolished by $\beta$-adrenoceptor blockade with propranolol.

9. Whereas reserpinization abolished the tyramine- and cocaineinhibitions, it did not affect the inhibitory actions of noradrenaline or of $\mathrm{PGE}_{2}$. 
10. Indomethacin and sodium meclofenamate, which suppress prostaglandin synthesis, did not affect the twitch-inhibiting actions of noradrenaline, tyramine or cocaine.

11. These results provide further support for the conclusion that post-ganglionic motor transmission to the vas deferens is non-adrenergic in these species and assign to endogenously released noradrenaline an inhibitory role upon motor transmission.

\section{INTRODUCTION}

In a previous investigation the conclusion was reached that the post-ganglionic motor transmitter in the guinea-pig vas deferens is not noradrenaline (Ambache \& Zar, 1971). Yet there is incontrovertible evidence for the presence of a rich adrenergic innervation in this organ and for its exceptionally high noradrenaline content in many species (Sjöstrand, 1962, 1965; Blakeley, Dearneley \& Harrison, 1970). Noting that noradrenaline actually inhibited post-ganglionic motor transmission, Ambache \& Zar $(1970 b, 1971)$ made the suggestion that the adrenergic innervation in the vas of this species might serve an inhibitory role, modulating the motor transmission. Since it is, as yet, not feasible to achieve a selective electrical stimulation of the adrenergic fibres running to the vas, an alternative approach based upon the use of two indirectly acting sympathomimetic drugs, tyramine and cocaine, has been adopted in the present investigation in an attempt to determine the physiological role of these fibres.

It is known that tyramine mimics the physiological effects of adrenergic nerve stimulation by releasing endogenous noradrenaline from its stores at adrenergic nerve terminals. It was therefore interesting to find that in the guinea-pig and rabbit vas deferens tyramine did, in fact, produce a pure inhibition of the post-ganglionic motor transmission, without any trace of contraction; reserpinization abolished this inhibition, thus relating it to the release of endogenous noradrenaline.

A reserpine-susceptible tyramine-inhibition of motor transmission could be detected also in rat vasa although, in this species, tyramine elicited a distinct contraction of the vas at the same time as it inhibited the twitches. However, the significant finding was made that, whereas the tyramine contraction (also reserpine-susceptible) was readily abolished by phenoxybenzamine or phentolamine, post-ganglionic motor transmission remained unaffected by these $\alpha$-adrenoceptor blocking 
agents or by reserpinization. This is a clear indication that the $\alpha$-adrenoceptors which are activated by endogenous noradrenaline are fully accessible to $\alpha$-blockers; hence, the resistance of post-ganglionic motor transmission to $\alpha$-blockade can no longer be explained away by invoking an inaccessibility of these adrenoceptors to $\alpha$-blocking drugs. The new findings with tyramine therefore confirm the existence of a non-adrenergic motor transmission in the rat as in the guinea-pig and rabbit vas. Similar results with cocaine support these conclusions and also strongly suggest a predominantly inhibitory role for the adrenergic innervation.

The brevity of the train length ( $<10$ pulses per train) used throughout this and in most of our earlier investigations on the vas deferens needs to be emphasized. From a survey of the literature it appears that much longer trains of stimuli (in some cases more than 300 pulses per train) have been in general use. This fact should be kept in mind when considering the discrepancy between some of our results and those of other workers; stimulation with single pulses or with short trains appears to give a less complicated and perhaps more physiological picture of events at these nerve-muscle junctions than does stimulation with long trains of pulses.

A preliminary account of these results has appeared elsewhere (Ambache, Dunk, Verney \& Zar, 1972).

\section{METHODS}

Albino guinea-pigs (0.3-1 kg), killed by concussion, and albino Wistar rats $(0.2-045 \mathrm{~kg})$, anaesthetized with ethyl chloride, were bled out; a few rabbits and two hamsters were also used. The method for desheathing and setting up the isolated vas deferens preparations in vitro at $35^{\circ} \mathrm{C}$ and a full description of essential experimental details, including the composition of the Krebs-Henseleit solution, have been given previously (Ambache \& Zar, 1971). In particular, the reader is referred to the earlier paper for procedural details of the intermittent field stimulation and for the evidence, given in Figs. 1 and 2 of that paper and based upon the use of a ganglion blocker or of tetrodotoxin, that the twitch responses were due entirely to excitation of post-ganglionic fibres. In most of the present experiments the pulse width was fixed at $1 \mathrm{msec}$ and the intermittence at 50 or $60 \mathrm{sec}$ intervals. As before, the train length was kept short: for the 
guinea-pig vasa, 3-8 pulses per train; and for the rat vasa, usually single pulses. All recordings were isometric at a resting tension of $c a$. $0.3 \mathrm{~g}$, achieved by setting up the preparations at an initial tension of $0.5 \mathrm{~g}$.

Reserpinization. The animals received two injections of reserpine phosphate solution $(5 \mathrm{mg} / \mathrm{ml}$. in distilled water) in a daily dose of $5 \mathrm{mg} / \mathrm{kg}$, s.c. on the first and I.P on the second, and were killed on the third day.

Drugs. With the exception of indomethacin (1-( $p$-chlorobenzoyl)-5-methoxy-2-methyl-indole-3-acetic acid) and $\mathrm{PGE}_{2}$, all other dosages refer to the respective salts, namely: atropine sulphate, cocaine hydrochloride, ( - )-noradrenaline bitartrate, phenoxybenzamine hydrochloride, phentolamine mesylate, propranolol hydrochloride, sodium meclofenamate and tyramine hydrochloride. We are indebted to Professor J. R. Vane for the gift of indomethacin and sodium meclofenamate; and to Dr. A. J. Plummer, Ciba, Summit, N. J., U.S.A., for the reserpine phosphate.

\section{RESULTS}

Effects of tyramine in vas deferens preparations from normal animals

\section{Guinea-pig vasa}

The vas deferens is reported to possess the highest noradrenaline content of any tissue (Iversen, 1967, Table 4.1). In the guinea-pig vas deferens the noradrenaline content is given as $10 \mu \mathrm{g} / \mathrm{g}$ by Sjöstrand (1965) and as 7.65-26.82 $\mu \mathrm{g} / \mathrm{g}$ by Blakeley et al. (1970). In all other situations the indirectly acting sympathomimetic drug, tyramine, is known to release endogenous noradrenaline from its stores at adrenergic nerve-endings (for references, see Iversen, 1967, pp. 181185). It is therefore reasonable to expect that in the vas deferens, too, tyramine would release adrenergic transmitter and thereby mimic its physiological action. If noradrenaline were the motor transmitter, the administration of tyramine should induce a contraction of adrenergic origin in the vas and should facilitate the motor transmission. Yet, we never succeeded in evoking the slighest contraction in guinea-pig vas deferens preparations with tyramine in doses of $0.5-50 \mu \mathrm{g} / \mathrm{ml}$. In fact, tyramine had the opposite action: it exerted an inhibitory 
effect upon the height of the twitch responses elicited by post-ganglionic field stimulation.

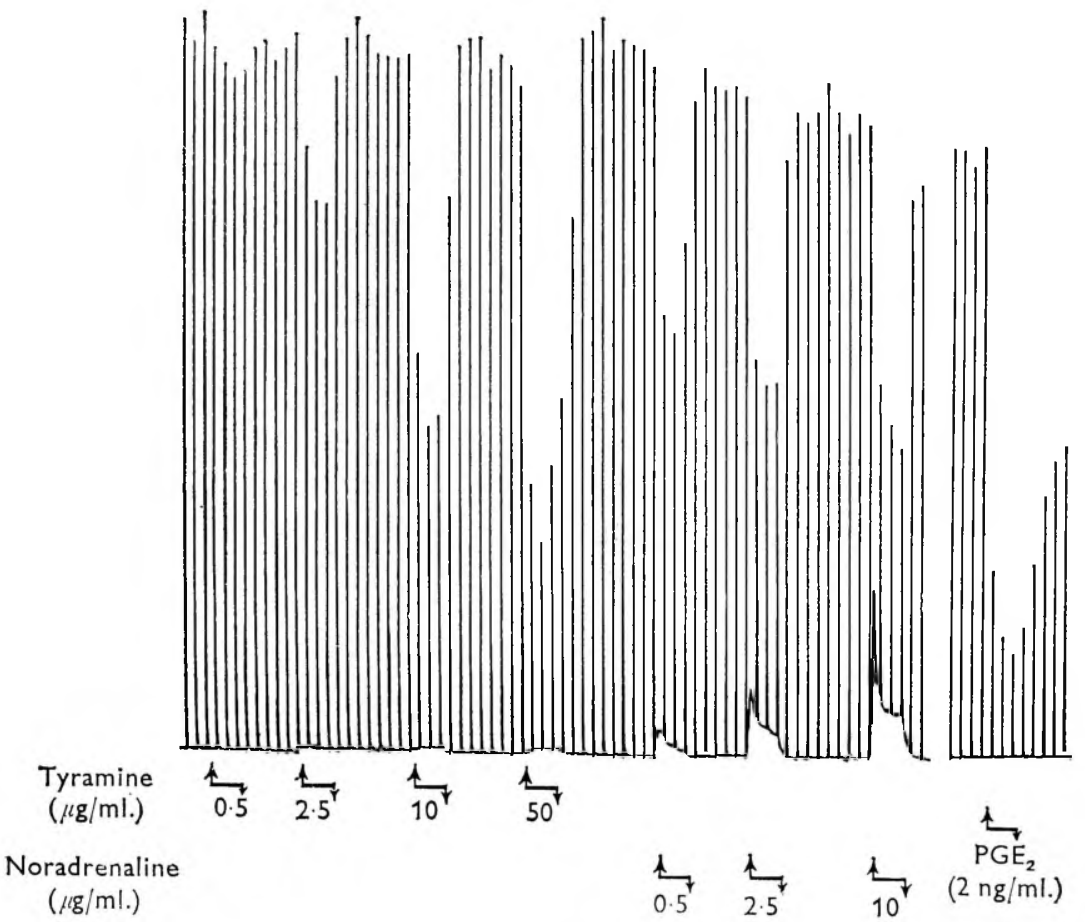

Fig. 1 - Inhibition by tyramine of post-ganglionic motor transmission in guineapig vas deferens. The twitches were elicited at 1 min intervals by field stimulation with trains of 8 pulses $(10 \mathrm{~Hz})$ of 1 msec duration and constant voltage. Between the arrows: tyramine, $0.5,2.5,10$ or $50 \mu \mathrm{g} / \mathrm{ml}$., produced graded inhibition; noradrenaline, $0.5-10 \mu \mathrm{g} / \mathrm{ml}$., likewise inhibited the twitches but evoked small contractions of the vas at the same time; lastly, twitch inhibition by $\mathrm{PGE}_{2}$, $2 \mathrm{ng} / \mathrm{ml}$. All drug contacts, $3 \mathrm{~min}$. See text.

In six experiments the inhibitory action of tyramine was examined at four dose levels, namely $0.5,2.5,10$ and $50 \mu \mathrm{g} / \mathrm{ml}$., the contact time being $3 \mathrm{~min}$ for each dose. The degree of inhibition was related to the concentration of tyramine in the organ-bath, as shown in Fig. 1. The results of these six experiments are summarized in the middle column of Table 1; the degree of inhibition at each dose level has been expressed as the mean per cent twitch-reduction ( \pm S.E. of the mean). The respective values for the degree of inhibition at the four dose levels were: $20.9 \% \pm 5.5 ; 38.4 \% \pm 9.15 ; 58 \% \pm 7.56$; and $64.1 \% \pm 8.85$. The pattern of deepening inhibition with increasing doses of tyramine is clear. 
TABLE $1-\%$ Twitch-inhibition $\dagger$ produced by noradrenaline, tyramine, cocaine and $\mathrm{PGE}_{2}$ in desheathed vas deferens preparations from normal and reserpinized guinea-pigs

\section{'Normal'}

$\begin{array}{lrlc}\text { Noradrenaline } & 0.5 \mu \mathrm{g} / \mathrm{ml} . & 29.1 \pm 3.7(6) & 26.3 \pm 10.3(3) \\ \text { Noradrenaline } & 2.5 \mu \mathrm{g} / \mathrm{ml} . & 39.05 \pm 4.6(6) & 38.3 \pm 8.4(3) \\ \text { Noradrenaline } & 10 \mu \mathrm{g} / \mathrm{ml} . & 48.5 \pm 5.5(5) & 55.1 \pm 13.3(3) \\ & & & \\ \text { Tyramine } & 0.5 \mu \mathrm{g} / \mathrm{ml} . & 20.9 \pm 5.5(6) & 0.6 \pm 0.6(3) \\ \text { Tyramine } & 2.5 \mu \mathrm{g} / \mathrm{ml} . & 38.4 \pm 9.1(6) & 0.7 \pm 0.7(3) \\ \text { Tyramine } & 10 \mu \mathrm{g} / \mathrm{ml} . & 58.0 \pm 7.6(6) & 4.9 \pm 4.9(3) \\ \text { Tyramine } & 50 \mu \mathrm{g} / \mathrm{ml} . & 64.1 \pm 8.8(6) & 9.0 \pm 4.6(3) \\ & & & 0.0(2) \\ \text { Cocaine } & 0.5 \mu \mathrm{g} / \mathrm{ml} . & 60.0(2) & 7.5(2) \\ \text { Cocaine } & 5 \mu \mathrm{g} / \mathrm{ml} . & 78.5(2) & 12 *(2) \\ \text { Cocaine } & 50 \mu \mathrm{g} / \mathrm{ml} . & 99.0(2) & 100.0(3) \\ & & & \end{array}$

Values are means $\pm \mathrm{S} . \mathrm{E}$. of mean. Number of experiments in brackets. The negative value, marked with an asterisk, indicates \% twitch-protentiation by cocaine.

$\dagger$ The twitches were elicited by trains of eight $1 \mathrm{msec}$ pulses $(10 \mathrm{~Hz})$.

It was of interest to compare this effect of tyramine with the twitch-inhibiting actions of noradrenaline and of $\mathrm{PGE}_{2}$, described earlier by Ambache \& Zar $(1970 a, b)$. Noradrenaline was examined at three dose levels, namely $0.5,2.5$ and $10 \mu \mathrm{g} / \mathrm{ml}$. (contact times of $3 \mathrm{~min}$ for each dose); the respective values for the mean \% twitchinhibitions were $29.1 \pm 3.73 ; 39.05 \pm 4.65$ and $48.5 \pm 5.5$. As with tyramine, the noradrenaline-inhibition was dose-related.

In preparations which were insensitive to the motor action of noradrenaline, a pure inhibition of the twitches -was recorded; but, in more sensitive preparations noradrenaline often produced small contractions in the guinea-pig vasa, as well as the inhibition of the electrically induced twitches (see Fig. 1). Large doses of noradrenaline, in excess of $10 \mu \mathrm{g} / \mathrm{ml}$., produced so much contraction of the vas as to render difficult the accurate assessment of the twitch inhibition.

$\mathrm{PGE}_{2}$ was tested as a single dose-level of $2 \mathrm{ng} / \mathrm{ml}$. For this drug a longer contact-time of 4-6 min was sometimes needed for the full development of the inhibitory effect; the degree of inhibition at this dose level was $90.5 \% \pm 3.9$ (Fig. 1 and Table 1 ).

The $\alpha$-adrenoceptor blocking drugs, phentolamine, $1-2 \times 10^{-6} \mathrm{~g} / \mathrm{ml}$., and phenoxybenzamine, $10^{-6}-10^{-\overline{5}} \mathrm{~g} / \mathrm{ml}$, partially or completely blocked the twitch inhibitions produced by noradrenaline and by tyra- 
mine; on the other hand, the twitch inhibition produced by $\mathrm{PGE}_{2}$ was not antagonized by phentolamine or by phenoxybenzamine.

\section{Rat vasa}

Two important species differences were noted. First, the marked, often total, inhibition of post-ganglionic transmission by $1-2 \mathrm{ng} / \mathrm{ml}$. of $\mathrm{PGE}_{2}$, which occurred unfailingly in the guinea-pig vasa, could not be obtained in the rat vas deferens preparations; the maximum inhibition ever recorded was $10 \%$. This was seen in one experiment only, at the unusually high dose-level of $10 \mathrm{ng} / \mathrm{ml}$. of $\mathrm{PGE}_{2}$; and there was no further increase in the degree of inhibition as the dose was stepped up to $50 \mathrm{ng} / \mathrm{ml}$. In several other experiments these doses, and even $500 \mathrm{ng} / \mathrm{ml}$, of $\mathrm{PGE}_{2}$ failed to produce any twitch inhibition whatsoever.

Secondly, whereas tyramine had never produced a contraction in the guinea-pig vasa, it strongly contracted all the rat preparations. This difference is probably due to the greater sensitivity of the rat vas deferens to the motor action of noradrenaline. Thus, in our experience, rat vasa without exception responded with strong contractions to noradrenaline, $1-2 \mu \mathrm{g} / \mathrm{ml}$., whereas the noradrenaline sensitivity of guinea-pig vasa was, as reported previously (Ambache \& Zar, 1971), extremely variable, ranging between 3.75 and $>125 \mu \mathrm{g} / \mathrm{ml}$; the noradrenaline contractions shown in Figs. 1, 2, 7 and 9 illustrate this species difference.

The tyramine contraction was accompanied by a simultaneous inhibition of the motor transmission; this could be detected by the fact that the height of the electrically induced twitches, now superimposed upon the tyramine contraction, was considerably reduced.

As in guinea-pig vasa, post-ganglionic motor transmission in the rat vas deferens preparations was not affected by phenoxybenzamine or by phentolamine, indicating the presence of a non-adrenergic motor transmitter in both species. On the other hand, the contractions elicited by tyramine were completely abolished, in parallel with noradrenaline contractions, by $\alpha$-adrenoceptor blockade sep up either by phenoxybenzamine or by phentolamine.

Fig. 2 illustrates several features of the actions of tyramine on the rat vas deferens in an experiment on the two vasa from the same animal; the experiment was conducted in the presence of atro- 
pine, $10^{-6} \mathrm{~g} / \mathrm{ml}$, and propranolol, $2 \times 10^{-6} \mathrm{~g} / \mathrm{ml}$. The first panel shows the twitches elicited by post-ganglionic field stimulation with single $1 \mathrm{msec}$ pulses delivered at $1 \mathrm{~min}$ intervals and, at $A$, the motor response to noradrenaline, $2.5 \mu \mathrm{g} / \mathrm{ml}$, administered for $1 \mathrm{~min}$. Tyramine, $25 \mu \mathrm{g} / \mathrm{ml}$, left in the organ-bath for $6 \mathrm{~min}$, evoked the powerful contraction seen at $B$. The peak of this contraction was reached in $c a .1 \mathrm{~min}$ and was followed by a gradual relaxation associated with pronounced rhythmic activity. When electrical stimulation was resumed during this relaxation phase, the twitches, which were now superimposed upon the tyramine contraction and the rhythmic movements, showed a progressive decline in height (asterisks in Fig. 2 ). On the other hand, the motor response to noradrenaline, given again at $C$ in a dose of $2.5 \mu \mathrm{g} / \mathrm{ml}$. during the last $1 \mathrm{~min}$ of the exposure to tyramine, was as great as, or even greater than, before.

The preparation was then treated with phenoxybenzamine, $10^{-6}$ $\mathrm{g} / \mathrm{ml}$., for $10 \mathrm{~min}$ (between $C$ and $D$ ). The total disappearance, thereafter, of the tyramine contraction, as illustrated at $D$, made it much easier now to assess the inhibitory effect of tyramine upon the twitches. The motor response to noradrenaline was also abolished by the phenoxybenzamine treatment (see $E$ ), again uncovering a slight inhibitory effect of noradrenaline upon the twitches. The presence of propranolol in the bath fluid throughout these experiments should exclude the involvement of $\beta$-adrenoceptors in the causation of inhibition by tyramine and by noradrenaline.

It was noticed that the inhibitory effect of tyramine and of noradrenaline was much more pronounced if a lower concentration of phenoxybenzamine was used for the induction of $\alpha$-adrenoceptor blockade. For instance, in the experiment of Fig. 2 (lower record) a $10 \mathrm{~min}$ treatment of the contralateral vas with phenoxybenzamine, $10^{-7} \mathrm{~g} / \mathrm{ml}$., was quite adequate to extinguish the motor actions of tyramine and of noradrenaline (cf. $H, I, J$ with $F$ and $G$ ). The use of this lower dosage of phenoxybenzamine appears to have the advantage of revealing better the inhibitory actions of tyramine and of noradrenaline, which were much more pronounced than at $D$ and $E$ after the exposure of the other vas to the higher concentration of phenoxybenzamine $\left(10^{-6} \mathrm{~g} / \mathrm{ml}\right.$. $)$. Thus, higher concentrations of phenoxybenzamine appear to antagonize slightly the inhibitory action of tyramine and of noradrenaline. Another $\alpha$-blocking agent, phento- 


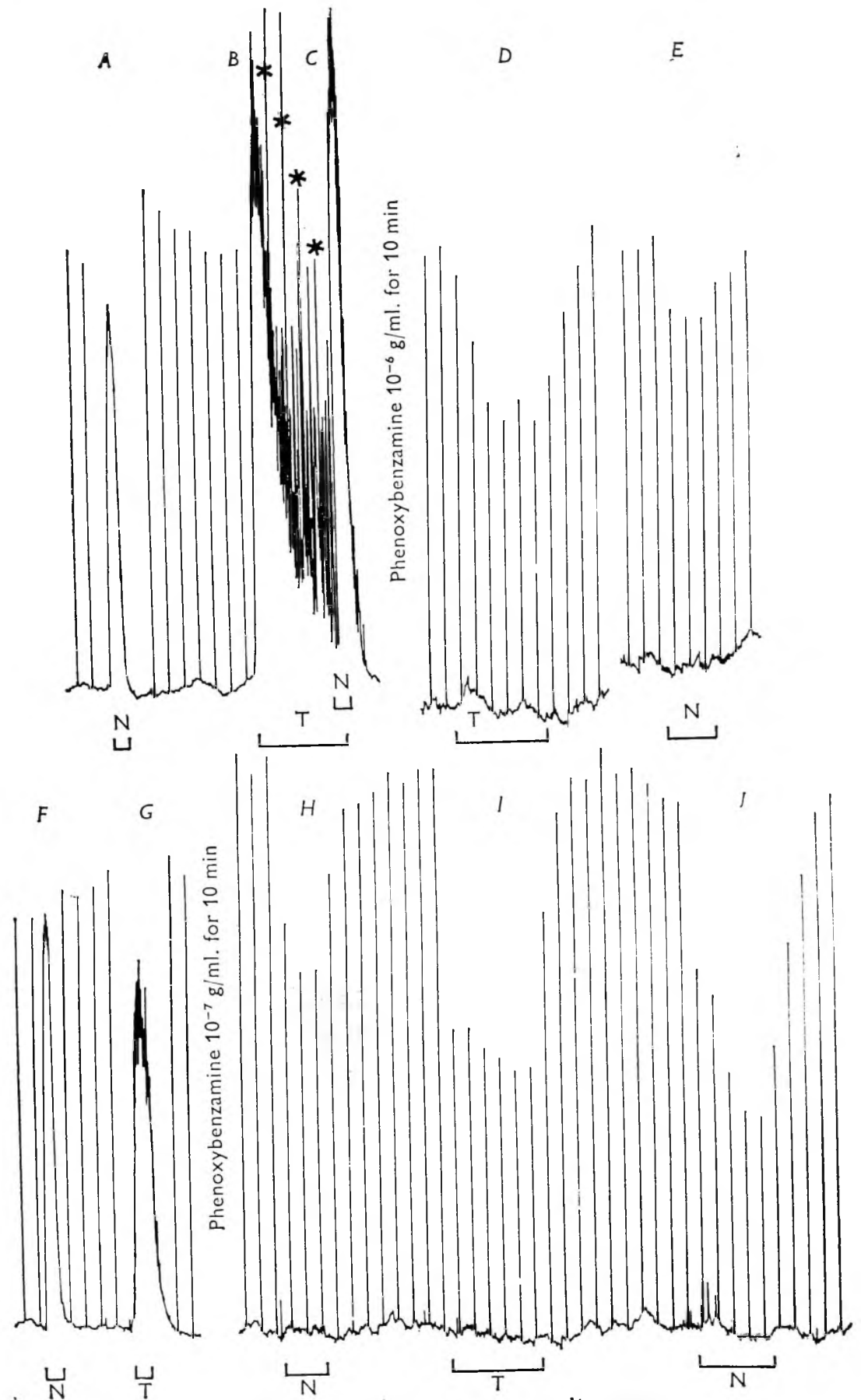

Fig. 2 - For legend see opposite page. 
lamine, $2 \times 10^{-6} \mathrm{~g} / \mathrm{ml}$, antagonized the inhibitory action of tyramine and of noradrenaline to a much greater extent than phenoxybenzamine.

\section{Loss of tyramine activity in vas deferens preparations from reserpinized animals}

\section{Guinea-pig vasa: absence of tyramine-inhibition}

In the vasa from guinea-pigs pre-treated with reserpine phosphate (hereafter termed 'reserpinized vasa') twitches were readily elicited by trains of 3-8 pulses of 1 msec duration delivered at $10 \mathrm{~Hz}$, though their height was often reduced (cf. Fig. 3 with Fig. 1). The sensitivity of the reserpinized vasa to the motor action of noradrenaline and to other spasmogens was markedly higher than that of the normal vasa, as reported by Westfall (1970). Nevertheless, tyramine never produced a contraction of the reserpinized guinea-pig vasa.

Reserpinization profoundly affected the inhibitory action of tyramine on the electrically induced twitches; the tyramine inhibition, which had never failed to occur in the normal vasa, was virtually absent in all the 'reserpinized' preparations. Table 1 summarizes the results of three such experiments and shows that in the 'reserpinized' vasa

\section{Legend to Fig. 2.}

Fig. 2 - Tyramine contracts the rat vas deferens and inhibits the twitches elicited by post-ganglionic stimulation; the tyramine contraction is abolished by phenoxybenzamine, $10^{-6} \mathrm{~g} / \mathrm{ml}$. (upper record) or $10^{-7} \mathrm{~g} / \mathrm{ml}$. (lower). Upper record from the left, and lower record from the right vas of the same animal; atropine, 10-6 $\mathrm{g} / \mathrm{ml}$., and propranolol, $2 \times 10^{-6} \mathrm{~g} / \mathrm{ml}$., present throughout. The twitches were elicited at $1 \mathrm{~min}$ intervals by single $1 \mathrm{msec}$ pulses of constant voltage.

Upper record: noradrenaline (N), $2.5 \mu \mathrm{g} / \mathrm{ml}$, administered at $A$ and $C$ for 1 min during interruption of electrical stimulation. At $B$, tyramine ( $\mathrm{T}), 25 \mu \mathrm{g} / \mathrm{ml}$., administered for $6 \mathrm{~min}$ with interruption of stimulation during the first and last $1 \mathrm{~min}$ of this exposure; the twitches elicited by electrical stimulation during the intervening $4 \mathrm{~min}$ are marked by asterisks. Between $C$ and $D, 10 \mathrm{~min}$ treatment with phenoxybenzamine, $10^{-6} \mathrm{~g} / \mathrm{ml}$. No interrruption of electrical stimulation during subsequente exposures to tyramine, $25 \mu \mathrm{g} / \mathrm{ml}$, for $6 \min$ at $D$ and to noradrenaline, $2.5 \mu \mathrm{g} / \mathrm{ml}$., for $3 \mathrm{~min}$ at $E$.

Lower record: contractions elicited, during interruptions of electrical stimulation, by $1 \mathrm{~min}$ exposures to noradrenaline, $2.5 \mu \mathrm{g} / \mathrm{ml}$., at $F$ and tyramine, $10 \mu \mathrm{g} / \mathrm{ml}$. at $G$. Between $G$ and $H, 10 \mathrm{~min}$ treatment with phenoxybenzamine, $10^{-7} \mathrm{~g} / \mathrm{ml}$. No interruption of electrical stimulation during subsequent exposures to noradrenaline, $2.5 \mu \mathrm{g} / \mathrm{ml}$. for $3 \mathrm{~min}$ at $H$ and $10 \mu \mathrm{g} / \mathrm{ml}$. for $5 \mathrm{~min}$ at $J$; and to tyramine, $10 \mu \mathrm{g} / \mathrm{ml}$., for $6 \mathrm{~min}$ at $I$. Note the greater inhibitions produced by tyramine and noradrenaline after treatment with the lower concentration of phenoxybenzamine. See text. 
the mean $0.6-9 \%$ twitch inhibition which tyramine produced at the four dose levels was insignificant when compared with the inhibitions of $20.9-64.1 \%$ found in the normal vasa.

A representative record obtained in a fourth experiment (not included in Table 1 ) is shown in Fig. 3; none of the four doses of tyramine $(0.5,2.5,10$ and $50 \mu \mathrm{g} / \mathrm{ml}$.) brought about any inhibition of the twitches. The unlikely possibility that the loss of the tyra-

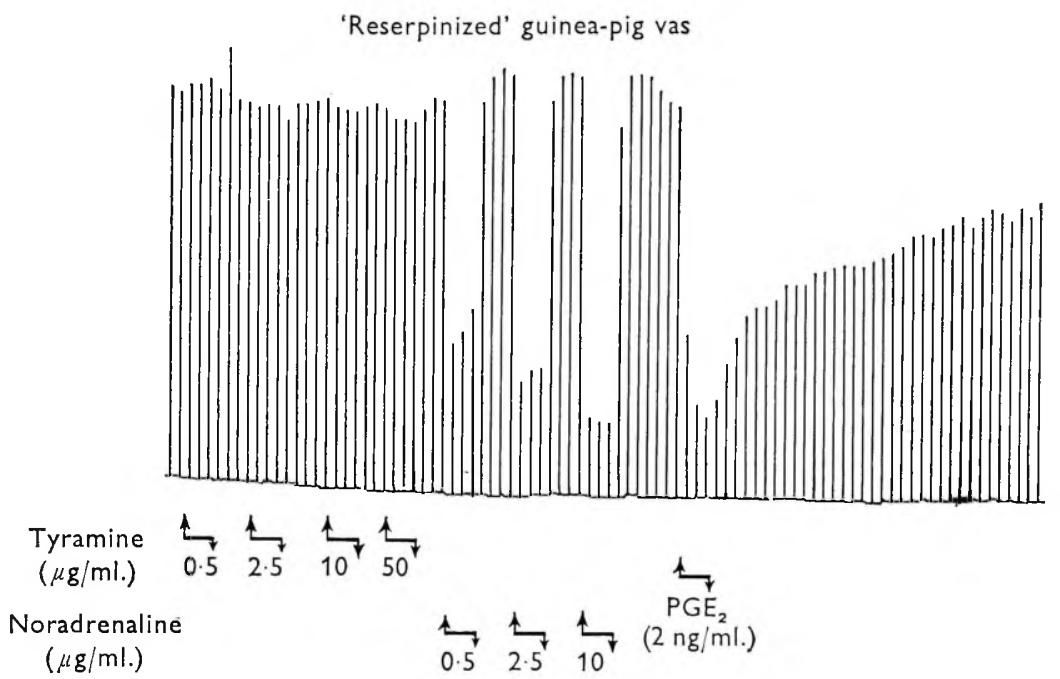

Fig. 3 - Effect of reserpinization in guinea-pig vas: the inhibition of postganglionic motor transmission by tyramine is lost, but noradrenaline and $\mathrm{PGE}_{2}$ retain their usual inhibitory action. The twitches were elicited at $1 \mathrm{~min}$ intervals by trains of eight 1 msec pulses $(10 \mathrm{~Hz}$ ) of constant voltage: recorder sensitivity twice that used in the experiment of Fig. 1, which serves as a control to this experiment. Drug contacts, $3 \mathrm{~min}$.

mine inhibition after reserpinization was due to a non-specific antagonism to all drugs producing inhibition in this preparation was discounted by the finding that the twitches could still be powerfully inhibited by noradrenaline and by $\mathrm{PGE}_{2}$ in the reserpinized as in the normal preparations.

In some of the experiments on reserpinized vasa the assessment of twitch inhibition by noradrenaline was hindered by the concurrent increase in sensitivity of the preparations to the motor effect of noradrenaline; this difficulty was overcome by a 10 min treatment with 
phenoxybenzamine, $10^{-7}$ or $10^{-6} \mathrm{~g} / \mathrm{ml}$., which abolished the motor response to noradrenaline and unmasked its inhibitory action. However, recourse to phenoxybenzamine was not necessary in the experiment illustrated in Fig. 3 because the preparation, even though reserpinized, failed to contract to noradrenaline, $10 \mu \mathrm{g} / \mathrm{ml}$; this is a good instance of the wide variation, among guinea-pigs, in the sensitivity of the vas to the motor action of noradrenaline, as mentioned on p. 48 .

Rat vasa: (a) absence of tyramine-contraction

In vasa taken from reserpinized rats the twitch responses to single pulses were comparable in size to those recorded from normal vasa (cf. upper and lower panels of Fig. 8, obtained at the same recorder sensitivity).

\section{'Reserpinized' rat vas}
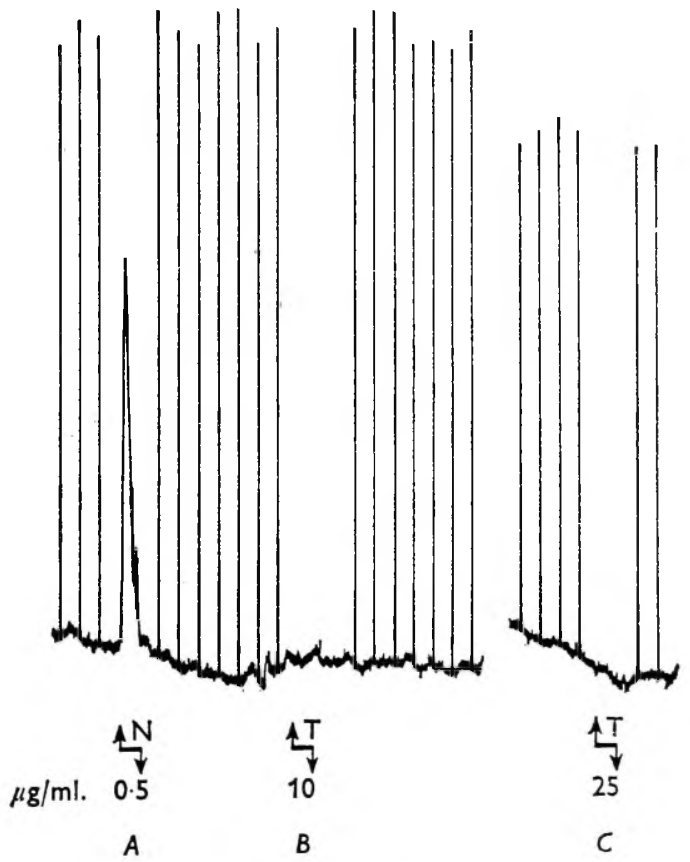

Fig. 4 - Effect of reserpinization in rat vas: loss of the tyramine contraction. The twitches were elicited at $1 \mathrm{~min}$ intervals by single $1 \mathrm{msec}$ pulses; atropine, 10-6 $\mathrm{g} / \mathrm{ml}$., and propranolol, $2 \times 10^{-6} \mathrm{~g} / \mathrm{ml}$., present throughout. Field stimulation was interrupted during drug contacts (1 min). At $A$, usual motor response to noradrenaline, $0.5 \mu \mathrm{g} / \mathrm{ml}$. At $B$ and $C$, absence of response to tyramine, 10 or $25 \mu \mathrm{g} / \mathrm{ml}$. 
Whereas normal rat vas deferens preparations had never failed to contract in response to tyramine, three reserpinized rat vasa all displayed a loss of the motor response to tyramine, $10-25 \mu \mathrm{g} / \mathrm{ml}$. Thus, in the experiment of Fig. 4, although the reserpinized vas preparation was more sensitive than usual to the motor action of noradrenaline $(0.5 \mu \mathrm{g} / \mathrm{ml}$. at $A)$, it was not contracted by tyramine, 10 $\mu \mathrm{g} / \mathrm{ml}$. at $B$ and $25 \mu \mathrm{g} / \mathrm{ml}$. at $C$. These results on reserpinized vasa indicate that the motor effect of tyramine found in normal rat vasa is due to an indirectly sympathomimetic action, i.e. to a release of endogenous noradrenaline from adrenergic endings. If we take this result in conjunction with the finding, mentioned earlier, that phenoxybenzamine abolishes the tyramine contraction of normal rat vasa as readily as it abolishes noradrenaline contraction, then it is clear that phenoxybenzamine is capable of blocking released, endogenous noradrenaline as easily as it blocks exogenous noradrenaline.

'Reserpinized' rat vas

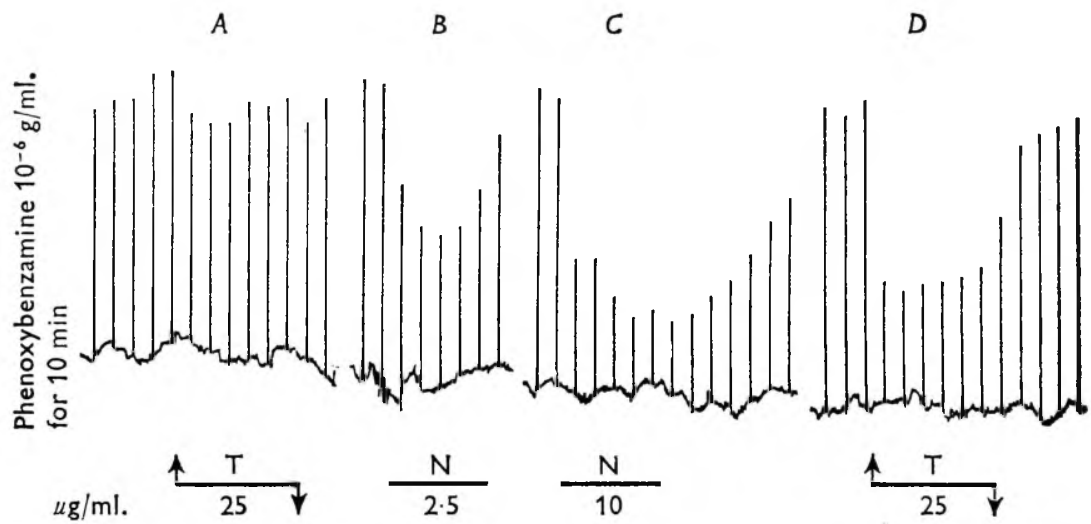

Fig. 5 - Effect of reserpinization in rat vas: loss of the tyramine inhibition of post-ganglionic motor transmission and restoration of the tyramine inhibition after treatment with large doses of noradrenaline. Contralateral vas to that used in the experiment of Fig. 4. The twitches were elicited at 1 min intervals by single $1 \mathrm{msec}$ pulses of constant voltage; atropine, $10^{-6} \mathrm{~g} / \mathrm{ml}$., and propranolol, $2 \times 10^{-6} \mathrm{~g} / \mathrm{ml}$., present throughout. The preparation was treated for $10 \mathrm{~min}$ with phenoxybenzamine, $10^{-6} \mathrm{~g} / \mathrm{ml}$., before panel 1 . At $\mathrm{T}$, tyramine, $25 \mu \mathrm{g} / \mathrm{ml}$., for $6 \mathrm{~min}$. At $\mathrm{N}$, noradrenaline, 2.5 or $10 \mu \mathrm{g} / \mathrm{ml}$., for $5 \mathrm{~min}$. See text.

(b) Absence of tyramine-inhibition. Unless preceded by several large doses of noradrenaline, tyramine never induced inhibition of the motor transmission in the reserpinized rat vasa; this is all the 
more significant in the absence of a motor response to tyramine, which should have rendered easier the detection of any inhibition. In fact, tyramine sometimes produced a slight potentiation of the twitches, which could be due to a direct stimulation of $\alpha$-adrenoceptors in the smooth muscle by the tyramine molecule per se, because this potentiation was abolished by phenoxybenzamine. Since in the normal rat vasa the tyramine inhibition of the twitches had been recorded more satisfactorily after the motor action of tyramine was blocked by phenoxybenzamine, the reserpinized vasa were also treated with phenoxybenzamine, $10^{-6} \mathrm{~g} / \mathrm{ml}$., for $10 \mathrm{~min}$. Fig. 5 shows the absence of tyramine inhibition in a reserpinized rat vas after such a treatment with phenoxybenzamine, and illustrates a further point of interest, namely the restoration of tyramine inhibition by exposures to large doses of noradrenaline. Thus, when tyramine was administered for $6 \mathrm{~min}$ at $A$ it produced a negligible degree of twitch inhibition. By contrast, there was a substantial inhibition of twitches when noradrenaline was administered $(2.5 \mu \mathrm{g} / \mathrm{ml}$. at $B$ and $10 \mu \mathrm{g} / \mathrm{ml}$. at $C$; both for $5 \mathrm{~min}$ ). These prolonged exposures to high concentrations of noradrenaline apparently led to some repletion of the noradrenaline stores in the preparation, because when tyramine, $25 \mu \mathrm{g} / \mathrm{ml}$., was repeated at $D$ it now produced considerable inhibition of the twitches.

\section{The inhibitory action of cocaine}

The sympathomimetic action of cocaine, unlike that of tyramine, is largely attributable to a prevention of the re-uptake or noradrenaline after its release by nerve impulses (Iversen, 1967). Field stimulation should excite all the fibres and endings in the vas, including those that are adrenergic. It is logical to expect that for the detection of this sympathomimetic action of cocaine, repetitive stimulation would be preferable to single pulses, because at higher noradrenaline outputs the re-uptake mechanism would become more important in the termination of adrenergic transmission. In the following experiments the vasa were therefore stimulated at 50 or $60 \mathrm{sec}$ intervals with trains of $3-8$ pulses at $10 \mathrm{~Hz}$.

\section{Guinea-pig vasa}

Post-ganglionic motor transmission in vas deferens preparations from normal guinea-pigs, i.e. untreated with reserpine, was inhibited 
by cocaine in remarkably low concentrations. For instance, in the experiment shown in the upper panel of Fig. 6, a $30 \%$ reduction in twitch-height was produced by the lowest concentration of cocaine used, namely $5 \times 10^{-8} \mathrm{~g} / \mathrm{ml}$. As the cocaine concentration was raised stepwise, the twitch reduction became more and more pronounced until, when a final concentration of $5 \times 10^{-5} \mathrm{~g} / \mathrm{ml}$. was reached, the twitches were completely abolished.

The following results show that this inhibitory effect of cocaine, particularly in lower concentrations, is due to a sympathomimetic rather than to its local anaesthetic action. When this experiment was repeated on reserpinized guinea-pig vasa (lower panel of Fig. 6), no trace of inhibition could be detected with cocaine in concentrations ranging between $5 \times 10^{-8}$ and $5 \times 10^{-5} \mathrm{~g} / \mathrm{ml}$. Only when the concentration of cocaine reached $10^{-4} \mathrm{~g} / \mathrm{ml}$., was there any twitch reduction; it is probable that at this high concentration cocaine was beginning to exert a local anaesthetic action upon the motor nerve fibres.

It is unlikely that the inhibition of the motor transmission by low concentrations of cocaine was due to a smooth-muscle depressant action because, at the height of the cocaine inhibition, noradrenaline contractions were in fact potentiated. This is illustrated in Fig. 7. The constancy of the motor response to noradrenaline, $20 \mu \mathrm{g} / \mathrm{ml}$., is shown at $A$ and $B$, before the administration of cocaine. A $5 \mathrm{~min}$ exposure to cocaine, $5 \mu \mathrm{g} / \mathrm{ml}$., produced an $86 \%$ reduction in twitch height at $C$, which was not reflected by any diminution in the motor response to noradrenaline; indeed, when noradrenaline was repeated at $D$ during the last $1 \mathrm{~min}$ of exposure to cocaine, its motor effect was greater than before.

Rat vasa

The results with cocaine in rat vasa were qualitatively similar to those obtained in guinea-pig vasa. In preparations taken from normal animals, i.e. untreated with reserpine, the inhibitions were seen best after a $10 \mathrm{~min}$ treatment with phenoxybenzamine, $10^{-7}$ $\mathrm{g} / \mathrm{ml}$. Even under these conditions the rat vasa proved to be considerably less sensitive to the inhibitory action of cocaine than guineapig vasa. As with guinea-pigs, reserpinization virtually abolished the inhibitory response of the rat vasa to cocaine. These features of the action of cocaine are illustrated in Fig. 8. The inhibition of the 

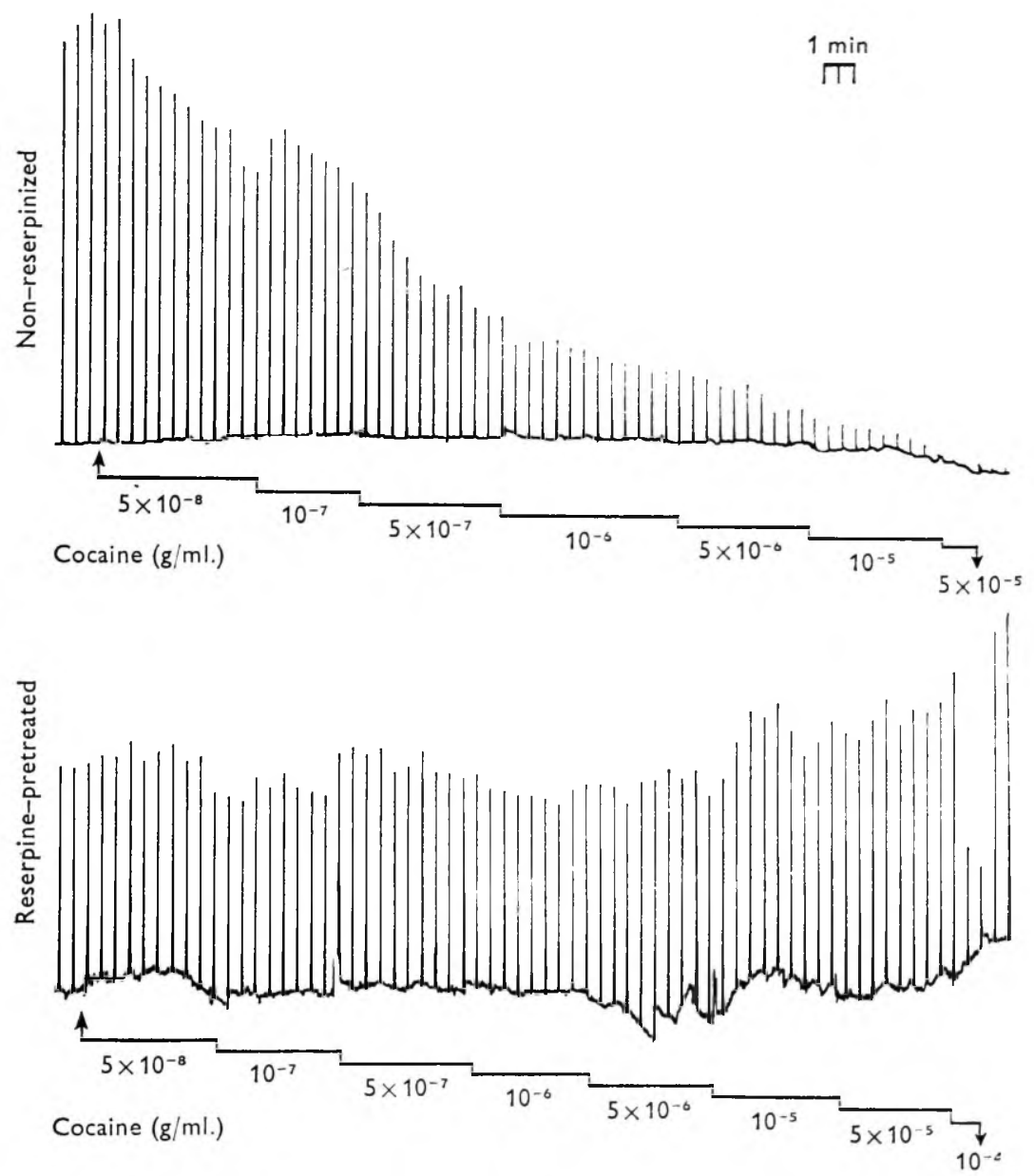

Fig. 6 - Guinea-pig vasa: comparison of the inhibitory effect of cocaine in a normal (upper record) and in a 'reserpinized' preparation (lower). The twitches were elicited at $50 \mathrm{sec}$ intervals by trains of 3 pulses $(10 \mathrm{~Hz})$ of $1 \mathrm{msec}$ duration and constant voltage. Both preparations were exposed to increasing concentrations of cocaine, as indicated, and washed between successive doses. With $5 \times 10^{-*}$ to $5 \times 10^{-5} \mathrm{~g} / \mathrm{ml}$. there is a marked inhibition of post-ganglionic motor transmission in the normal but none in the reserpinized vas. See text.

twitch responses produced in a normal preparation by cocaine at three concentration levels, 5, 10 and $50 \mu \mathrm{g} \mathrm{ml}$., is shown in panels $A-C$. In a corresponding experiment conducted under identical conditions on a preparation taken from a reserpinized rat, the most notable feature was the total lack of inhibition by cocaine, 5-10 $\mu \mathrm{g} \mathrm{ml}$. (panels 


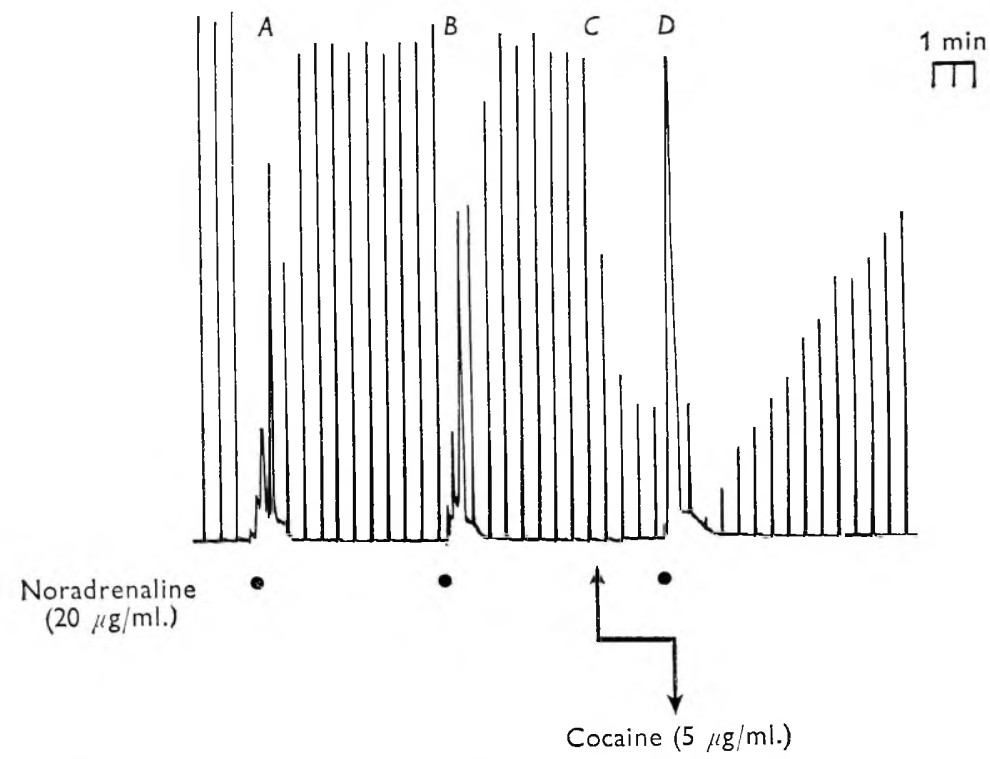

Fig. 7 - Guinea-pig vas: cocaine inhibits post-ganglionic motor transmission but potentiates the motor action of noradrenaline. The twitches were elicited at $50 \mathrm{sec}$ intervals by trains of 8 pulses $(20 \mathrm{~Hz})$ of 1 msec duration and constant voltage. At the dots, noradrenaline, $20 \mu \mathrm{g} / \mathrm{ml}$., for $1 \mathrm{~min}$. Between the arrows, cocaine, $5 \mu \mathrm{g} / \mathrm{ml}$., for $5 \mathrm{~min}$. See text.

$D$ and $E$ ) and the negligible inhibitory response to $50 \mu \mathrm{g} / \mathrm{ml}$. at $F$; this was followed by a potentiation when the drug was washed out.

Failure of inhibitors of prostaglandin synthesis to diminish the inhibitory actions of noradrenaline, tyramine and cocaine

The high inhibitory potency of some prostaglandins towards postganglionic motor transmission in the guinea-pig vas deferens was noted by Euler and Hedqvist (1969) and by Ambache and Zar (1970a). It has been suggested by Swedin (1971) that the inhibitory effect of noradrenaline in the vas deferens might be due to an indirect action involving an intermediate release of endogenous prostaglandin by noradrenaline. This possibility has been put to the test by the use of two drugs which are known to suppress the synthesis of prostaglandin, namely indomethacin and sodium meclofenamate; it has been reported by Gryglewski \& Vane (1971) that tissue prostaglandinsynthesis is totally abolished in vitro by both these drugs.

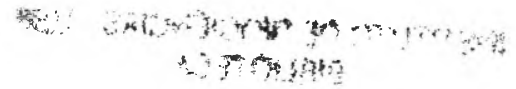



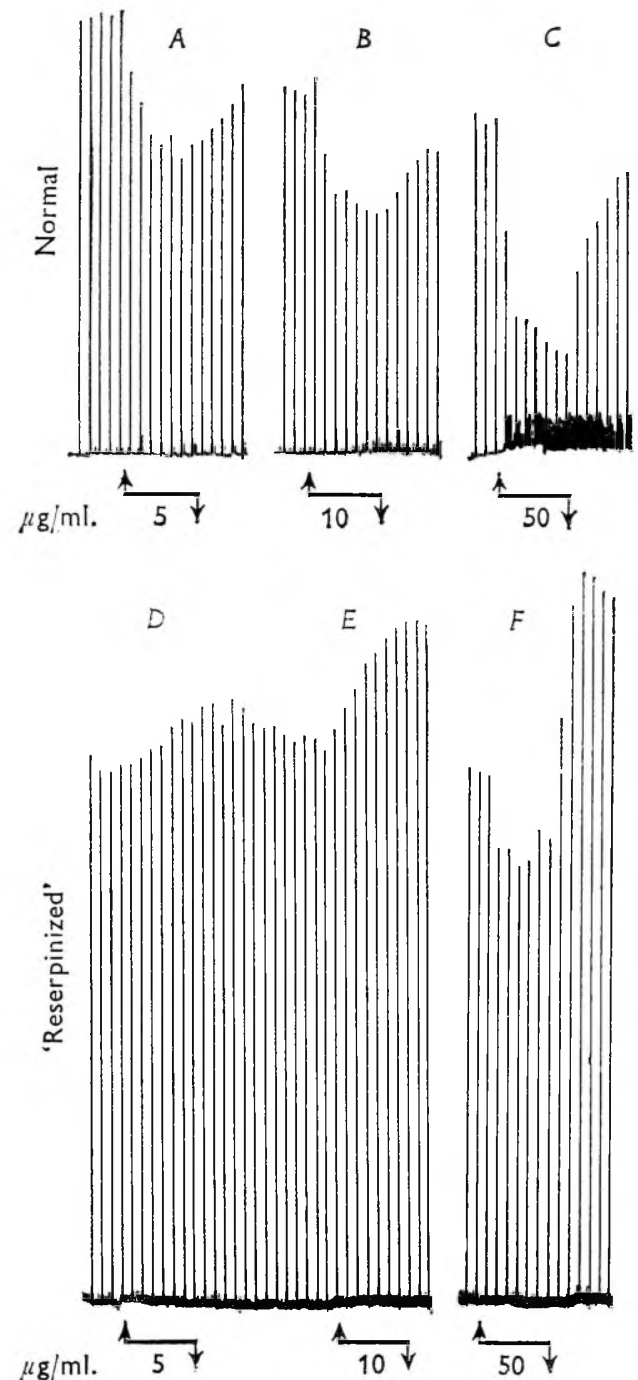

Fig. 8 - Rat vasa: comparison of the inhibitory effect of cocaine in a normal (upper record) and in a 'reserpinized' (lower) preparation. The twitches, recorded at the same sensitivity in both experiments, were elicited at $1 \mathrm{~min}$ intervals by trains of eight $1 \mathrm{msec}$ pulses $(10 \mathrm{~Hz})$ of constant voltage; atropine, $10^{-6} \mathrm{~g} / \mathrm{ml}$., and propranolol, $10^{-6} \mathrm{~g} / \mathrm{ml}$,, present throughout. Between the arrows, $7 \mathrm{~min}$ exposures to cocaine, $5-50 \mu \mathrm{g} / \mathrm{ml}$., as indicated. Reserpinization has completely abolished or reversed the inhibitory effect of the 5 and $10 \mu \mathrm{g} / \mathrm{ml}$. doses, and has greatly reduced the effect of the $50 \mu \mathrm{g} / \mathrm{ml}$. dose. 
Prolonged treatment of guinea-pig vas deferens preparations with indomethacin or sodium meclofenamate, during which the intermittent electrical stimulation was continued, did not diminish the inhibitory effect of noradrenaline; likewise, the inhibitions produced by the indirectly acting sympathomimetic drugs, tyramine and cocaine, remained undiminished or were even enhanced.

Fig. 9 illustrates two such experiments. Both preparations were subjected to field stimulation at 1 min intervals with trains of 8 pulses $(10 \mathrm{~Hz})$ of $1 \mathrm{msec}$ duration. The effect of tyramine and of noradrenaline on postganglionic motor transmission was tested at approximately hourly intervals, both before and during exposure to indomethacin or sodium meclofenamate. It can be seen that the inhibitory actions of noradrenaline and of tyramine were not diminished even after $c a$. $3 \mathrm{hr}$ exposure to $2 \times 10^{-6} \mathrm{~g} / \mathrm{ml}$. of indomethacin (upper record) or of sodium meclofenamate (lower record). Indeed, the upper record shows that there has been a substantial enhancement of the inhibitory actions of noradrenaline and of tyramine.

\section{Action of tyramine and of cocaine in other species}

A few experiments were carried out on rabbit vas deferens preparations. In vasa taken from normal rabbits noradrenaline, 1-5 $\mu \mathrm{g} /$ ml., produced a contraction followed by inhibition of the twitches elicited by electrical stimulation with trains of $1-5$ pulses $(10 \mathrm{~Hz})$. The response to tyramine, $2.5-25 \mu \mathrm{g} / \mathrm{ml}$., was the same as in guineapig vasa, i.e. tyramine inhibited post-ganglionic motor transmission without eliciting any contraction of the smooth muscle. Cocaine, 5-50 $\mu \mathrm{g} / \mathrm{ml}$, also inhibited motor transmission. In preparations taken from reserpinized rabbits post-ganglionic motor transmission persisted but the inhibitory effects of tyramine and cocaine were substantially reduced or abolished.

On the other hand, a preparation taken from a normal hamster behaved like the rat vasa in that it was contracted by tyramine, 25 $\mu \mathrm{g} / \mathrm{ml}$.; phenoxybenzamine, $10^{-6} \mathrm{~g} / \mathrm{ml}$., abolished this contraction and revealed an inhibitory effect of tyramine upon motor transmission. In a preparation taken from a reserpinized hamster both the motor and inhibitory effects of tyramine were lost; the reserpinization did not affect motor transmission. 


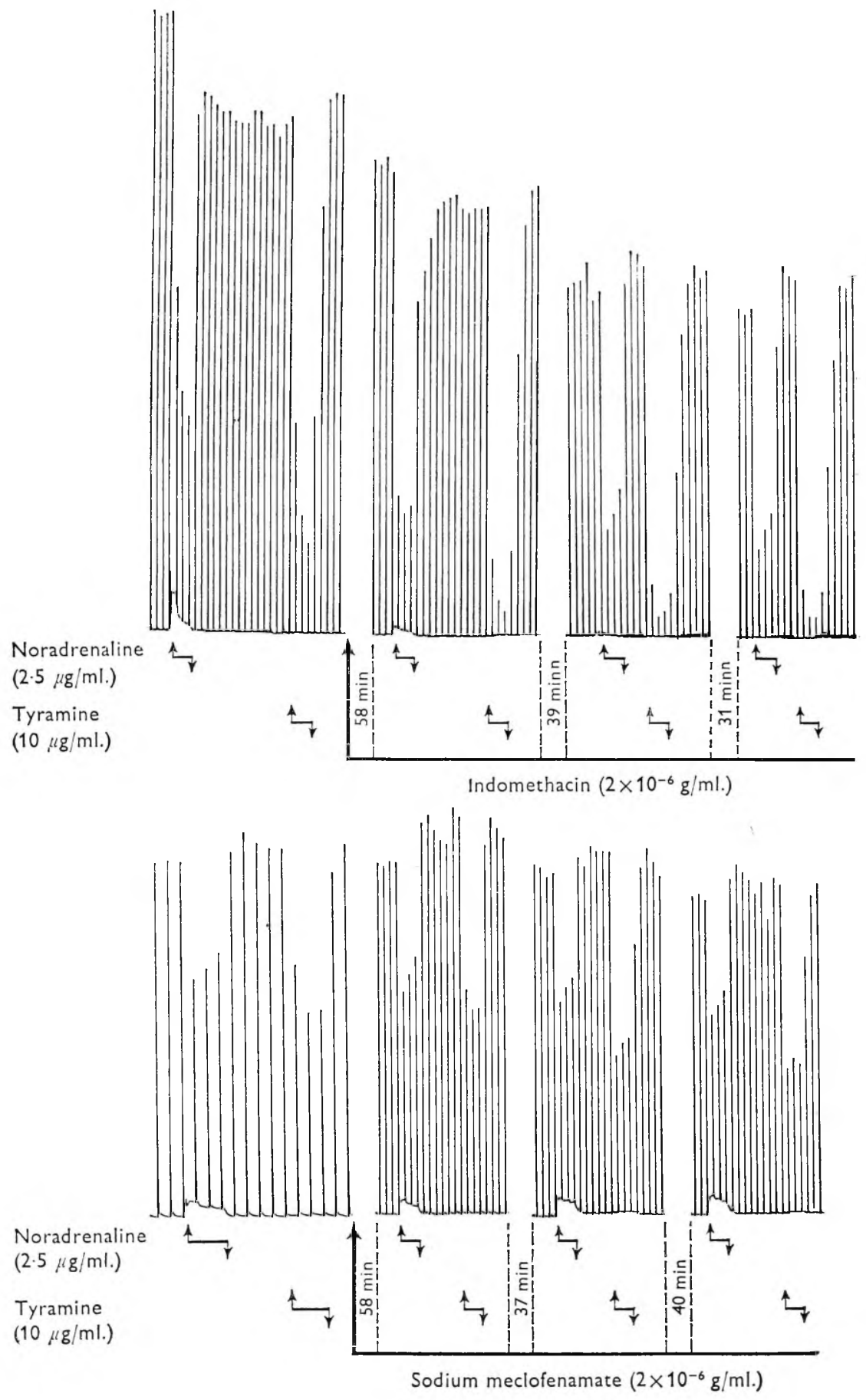

Fig. 9 - For legend see opposite page. 


\section{DISCUSSION}

Hotta (1969) has reported a tyramine inhibition of twitches elicited by preganglionic stimulation of the hypogastric nerve in the guineapig vas deferens; the interpretation of his results is complicated by the possibility of an action on the ganglionic synapses present in his preparations. This drawback has been avoided by the desheathing of our preparations, which renders them ganglion-free and restricts pharmacological effects on transmission to the post-ganglionic junctions.

The present investigation has been based upon the assumption that in the vas, as elsewhere, tyramine and cocaine act predominantly as indirect sympathomimetic agents: tyramine, by releasing endogenous noradrenaline, and cocaine, by prolonging the action of endogenous noradrenaline after its release by electrical stimulation; in each case, the efficacy of these drugs would depend upon functional integrity of the adrenergic nerve-endings. This assumption is fully supported by our finding that after reserpinization tyramine and cocaine lost their effectiveness. Hence, their actions in normal vasa can be justifiably interpreted in terms of an intermediate release of endogenous noradrenaline, and thereby provide a strong hint of the probable physiological function of the adrenergic innervation in the vas.

For a proper understanding of the physiological role of these adrenergic nerves it must be kept in mind that there is a wide variation, not only between species but also within a species, in the sensitivity of the vas longitudinal muscle to the motor action of noradrenaline (Ambache \& Zar, 1971); such variation is perhaps explicable on the basis of a variable number of available motor $\alpha$-adrenoceptors. Of the species examined in this paper the guinea-pig and rabbit were the least sensitive to the vascontracting action of noradrenaline and therefore provided a clearer picture of the physiological role of endogenous

Legend to Fig. 9.

Fig. 9 - Vasa from two guinea-pigs. The inhibitory effects of noradrenaline and of tyramine remain unaffected by exposures for $>3 \mathrm{hr}$ to the inhibitors of prostaglandin synthesis, indomethacin or sodium meclofenamate, $2 \times 10^{-6} \mathrm{~g} / \mathrm{ml}$. (upper and lower records, respectively). In both preparations the twitches were elicited at $1 \mathrm{~min}$ intervals by trains of eight $1 \mathrm{msec}$ pulses $(10 \mathrm{~Hz})$ of constant voltage. The inhibitions produced by fixed doses of noradrenaline or of tyramine ( 3 min contacts) are shown before, and at approximately hourly intervals during, the exposure to indomethacin or sodium meclofenamate. The first panel of the fower tracing was recorded at twice the usual paper speed. 
noradrenaline, which here appears to be purely inhibitory. Thus, in the guinea-pig and rabbit vasa tyramine never evoked a contraction; unfailingly, its action was to inhibit motor transmission and it is significant that this inhibition was absent from the reserpinized preparations. Hence, it would follow that in these two species post-ganglionic motor transmission to the vas cannot be adrenergic and that the likeliest function of the adrenergic innervation is to inhibit the motor transmission. The fact that the inhibition produced by tyramine or by cocaine was obtained in the presence of propranolol indicates that $\beta$-adrenoceptors play no part in its genesis; this is in keeping with our earlier finding that noradrenaline-inhibition is not mediated by $\beta$-adrenoceptors (Ambache \& Zar, 1971).

In the rat vas deferens the picture is more complex. The greater sensitivity, in this species, of the muscle fibres to the motor action of noradrenaline resulted in a dual effect of tyramine: there was a propranolol-resistant inhibition of motor transmission, but this was accompanied by a contraction of the smooth muscle. Both effects were due to endogenous noradrenaline because they were absent after reserpinization. This raises the question as to which of these two effects of tyramine, the inhibition of transmission or the contraction of the muscle, is mimicking the physiological function of the adrenergic nerves in the rat vas deferens. In this context, the differential effect of $\alpha$-adrenoceptor blocking drugs on the tyramine contraction, on the one hand, and on the electrically induced twitches, on the other, acquires more importance. The tyramine contraction of the normal rat vasa was completely blocked by low concentrations of phenoxybenzamine or of phentolamine, but post-ganglionic motor transmission remained unaffected by these $\alpha$-blockers. This finding has the following theoretical implications. Post-ganglionic motor transmission in the vas deferens has hitherto been widely considered to be adrenergic and, in order to account for its resistance to $\alpha$-adrenoceptor blockade, it has been suggested (e.g. Holman, 1970) that the motor $\alpha$-adrenoceptors which are activated by endogenous noradrenaline in the longitudinal muscle of the vas are inaccessible to $\alpha$-blockers. Our present finding does not support this view. The contraction induced by endogenous noradrenaline in rat vasa on administration of tyramine is fully susceptible to $\alpha$-blockade by phentolamine or phenoxybenzamine, and there is therefore no ground for the belief that the $\alpha$-adrenoceptors in this smooth muscle possess anomalous properties of inaccessibility or resistance to $\alpha$-blocking agents. Furthermore, it has been pointed 
out by Hotta (1969) that electron microscopy of the guinea-pig vas deferens has failed to provide histological evidence for any structure acting as a diffusion barrier which would prevent the entry of drugs into the junctional area.

Besides its post-synaptic action due to combination with motor $\alpha$-adrenoceptors in the smooth muscle, phenoxybenzamine can also act presynaptically, on noradrenaline re-uptake. It is conceivable that phenoxybenzamine might block the action of tyramine by preventing its entry into the adrenergic nerves. However, such a presynaptic basis for the extinction of the tyramine contraction in our experiments appears unlikely, because phentolamine was as efficient as phenoxybenzamine in abolishing this tyramine contraction and because noradrenaline-depletion by reserpine also abolished the motor effect of tyramine. But perhaps the clearest indication of a post-synaptic locus for this phenoxybenzamine action was our finding that, at a concentration of $10^{-7} \mathrm{~g} / \mathrm{ml}$., phenoxybenzamine did not prevent the release of noradrenaline by tyramine and the consequent inhibition of motor transmission. Therefore, the presynaptic action of tyramine on the adrenergic nerves appears to remain unimpaired by the treatment with phenoxybenzamine and the absence of a motor effect of tyramine under these selfsame conditions should be attributed to $\alpha$-adrenoceptor blockade in the smooth muscle.

At the same time as it contracted the rat vas deferens tyramine inhibited the twitches elicited by electrical stimulation. After $\alpha$-blockade by phenoxybenzamine this inhibition of post-ganglionic motor transmission was seen more clearly, as it was now unaccompanied by the tyramine contraction. Therefore, it appears that there is no essential difference between the rat and the guinea-pig with regard to the inhibitory action of endogenous noradrenaline on motor transmission. Since there is this clear correspondence in susceptibility of post-ganglionic motor transmission to inhibition by endogenous noradrenaline in both species, it is tempting to assign a primarily inhibitory role to the adrenergic innervation of the rat as of the guineapig vas. At the same time it is evident that, when the muscle fibres are exceptionally sensitive to noradrenaline, e.g. in rat and a proportion of guinea-pig vasa, the overspill of endogenous noradrenaline to the motor $\alpha$-adrenoceptors in the muscle engenders a second effect, exemplified by the spasm seen in rat vasa. Such an effect could occur not only after the administration of tyramine but also after 
hypogastric nerve or field stimulation with long trains of pulses, e.g. the 'second phase' of Swedin (1971). This recent work by Swedin on the neurotransmission mechanism in the rat and guinea-pig vas deferens is of considerable relevance to our results. Field stimulation with short trains of 10-40 pulses induced 'immediate' rapid twitches, which should correspond to the responses studied by us, using few pulses, in the present and in earlier investigations (Ambache \& Zar, $1970 a, b, 1971)$; indeed, Swedin has confirmed our finding that these twitches are resistant to $\alpha$-adrenoceptor blocking agents and are inhibited by $\mathrm{PGE}_{2}$. With much longer trains of 120 pulses, another motor component ('the second, slower phase') appeared in Swedin's records; unlike the twitches, this component was susceptible to $\alpha$-adrenoceptor blockade but was not inhibited by $\mathrm{PGE}_{2}$. Swedin considered that both components were due to the same transmitter substance, noradrenaline; he attributed the initial twitch to activation of 'junctional' receptors close to the nerve endings and presumed to be inaccessible to $\alpha$-blockers, and the second, slow phase to an activation of more distant 'extrajunctional' receptors susceptible to $\alpha$-blockade.

Swedin's hypothesis is contradicted by our tyramine results, which in fact negate the existence of adrenoceptors inaccessible to $\alpha$-blocking agents. Since his hypothesis assumes the mediation both of the 'immediate' twitch and of the second, slow phase by a single neurotransmitter, i.e. noradrenaline, it would also fail to explain his own findings that prostaglandin selectively inhibited the first phase and reserpine selectively abolished the second. This hypothesis also leads to the contradiction that prostaglandin, at the same time as it suppresses the noradrenaline output sufficiently to abolish the first phase (presumed due to the activation of junctional adrenoceptors), allows the much greater release of noradrenaline needed for the activation of the more distant extrajunctional adrenoceptors. Swedin's findings are easier to understand if we assume that the first phase is due to the non-adrenergic motor transmission proposed earlier by us, and the second phase to an overspill of noradrenaline. Our latest results suggest that the principal function of endogenous noradrenaline is to inhibit the post-ganglionic motor transmission; but that after a very large number of pulses the release of endogenous noradrenaline assumes such proportions as to cause an overspill to motor $\alpha$-adrenoceptors in the smooth muscle (Swedin's 'extrajunctional receptors).

The work by Hotta (1969) mentioned above includes an electrophysiological investigation of the excitatory junction potentials (e.j.p.s.) 
in the guinea-pig vas deferens, which lends strong support to these views. The application of exogenous noradrenaline, $3 \times 10^{-6} \mathrm{~g} / \mathrm{ml}$., caused a reduction in the amplitude of e.j.p.s without any change in resting potential, i.e. without depolarization or hyperpolarization; this inhibitory effect of noradrenaline was not antagonized by nethalide, a $\beta$-adrenoceptor blocking agent, nor by dibenamine in doses adequate to block the other action of noradrenaline, exerted directly on $\alpha$-adrenoceptors in the smooth muscle fibres. The inhibitory action of noradrenaline on the e.j.p.s appears to provide the basis for the inhibitory effects described here.

Histologically, a synaptic relationship between adrenergic and nonadrenergic nerve terminals in the cat and guinea-pig vas deferens has been revealed by electron microscopy. Thoenen, Tranzer, Hürlimann \& Haefely (1966) have referred to the presence, in close juxtaposition, of $(\alpha)$ adrenergic nerve terminals, characterized by dark granular vesicles which filled with osmiophilic material after incubation of the tissue with noradrenaline; and $(b)$ non-adrenergic nerve terminals characterized by vesicles which remained 'empty' and did not take up any osmiophilic material after noradrenaline incubation. The two types of endings were found 'lying membrane to membrane, enclosed in the same Schwann cell'; this close arrangement is clearly illustrated in Figs. 6 and 7 of their paper. In interpreting these observations, Thoenen et al. (1966) made the assumption that the non-adrenergic terminals with the empty vesicles were cholinergic because of their resemblance to nerve endings found in the cat iris. However, an empty appearance of synaptic vesicles is no sure guide to the chemical identity of the transmitter within them. Our previous findings with atropine and anticholinesterases rule out any significant cholinergic component in the motor transmission at the post-ganglionic endings in the vas; it would seem therefore, that the empty-vesicled non-adrenergic terminals might well be the post-ganglionic motor nerve endings containing the unknown motor transmitter and that the closeness to them of the 'osmiophilic' adrenergic terminals would allow easy access to them for the endogenous noradrenaline released by the other endings, thus permitting a synaptic interplay between the two types of nerve terminals.

We wish to thank our colleague Dr. G. C. R. Morris for reading the manuscript and Messrs P Miall, P. Smith and P. Richardson for valuable assistance. 
AMBACHE, N. \& ZAR, M. ABOO (1970a) - An inhibitory effect of prostaglandin $\mathrm{E}_{2}$ on neuromuscular transmission in the guinea-pig vas deferens. $J$. Physiol. 208:30-32 $P$.

AMBACHE, N. \& ZAR, M. ABOO (1970b) - Motor transmission in the vas deferens; the inhibitory action of noradrenaline. Br. J. Pharmac. 40:556-558 $P$.

AMBACHE, N. \& ZAR, M. ABOO (1971) - Evidence against adrenergic motor transmission in the guinea-pig vas deferens. $J$. Physiol. 216:359-389.

AMBACHE, N., DUNK, L. P., VERNEY, J. \& ZAR, M. ABOO (1972) - Inhibitory nature of the adrenergic innervation in the guinea-pig vas deferents. $B r . J$. Pharmac. 44:359-360 $P$

BLAKELEY, A. G. H., DEARNALEY, D. P. \& HARRISON, VICTORIA (1970) The noradrenaline content of the vas deferens of the guinea-pig. Proc. $R$. Soc. B 174:491-502.

EULER, U. S. v. \& HEDQVIST, P. (1969) - Inhibitory action of Prostaglandins $\mathrm{E}_{1}$ and $\mathrm{E}_{2}$ on the neuromuscular transmission in the guinea-pig vas deferens. Acta physiol. scand. $7 \mathrm{y}: 510-512$.

GRYGLEWSKI, R. \& VANE, J. R. (1971) - Rabbit-aorta contracting substance (RCS) may be a prostaglandin precursor. Br. J. Pharmac. 43:420-421 P

HOLMAN, M. E. (1970) - Junction potentials in smooth muscle. In Smooth Muscle, ed. BÜLBRING, E., BRADING, A., JONES, A. \& TOMITA, T., pp. 244-288. London: Edward Arnold.

HOTTA, Y. (1969) - Some properties of the junctional and extrajunctional receptors in the vas deferens of the guinea-pig. Agents \& Actions 12:13-21.

IVERSEN, L. L. (1967) - The Uptake and Storage of Noradrenaline in Sympathetic Nerves. Cambridge: Cambridge University Press.

SJöSTRAND, N. O. (1962) - Effect of reserpine and hypogastric denervation on the noradrenaline content of the vas deferens of the guinea-pig. Acta physiol. scand. 56:376-380.

SJÖSTRAND, N. O. (1965) - The adrenergic innervation of the vas deferens and the accessory male genital glands. Acta physiol. scand. 65, suppl. 257.

SWEDIN, G. (1971) - Studies on neurotransmission mechanisms in the rat and guinea-pig vas deferens. Acta physiol. scand. 83, suppl. 369.

THOENEN, H., TRANZER, J. P., HÜRLIMANN, A. \& HAEFELY, W. (1966) Untersuchungen zur Frage eines cholinergischen Gliedes in der post-ganglionären sympathischen Transmission. Helv. physiol. pharmac. Acta, 24:229-246.

WESTFALL, D. P. (1970) - Nonspecific supersensitivity of the guinea-pig vas deferens produced by decentralization and reserpine treatment. $B r$. J. Pharmac. $39: 110-120$. 
